\title{
Peroxide Index, Trans Fatty Acids, Acrylamide and Polycyclic Aromatic Hydrocarbons (Pah) Contents in Frying Oils and Fried Tuna Fish Involved in "Garba" Production in Côte d'Ivoire
}

\author{
Massogbè Diabate ${ }^{1 *}$, Daouda Nimaga ${ }^{2 *}$, Charlemagne Nindjin ${ }^{1}$, Virgile Ahyi ${ }^{3}$, Joseph Dossou ${ }^{4}$, \\ N'Guessan Geoges Amani ${ }^{1}$
}

\author{
${ }^{1}$ Laboratory of Food Biochemistry and Tropical Products Transformation (LBATPT), University of Nangui Abrogoua, Abidjan, \\ Côte d'Ivoire \\ ${ }^{2}$ Department of Engineering Agronomy, Forest and Environment, University of Man, Man, Côte d'Ivoire \\ ${ }^{3}$ Laboratory of IRGIB Africa Institute, IRGIB Africa Institute of Cotonou, Cotonou, Benin \\ ${ }^{4}$ Laboratory of Food Processing Bioengineering (LABIOPA), University of Abomey Calavi, Cotonou, Benin \\ Email: ^masso.diabate@gmail.com, *daonimaga@yahoo.fr, charlemagne.nindjin@yahoo.fr, \\ ahyivirgile@yahoo.fr, jokdossou@yahoo.fr, amanigeorges@yahoo.fr
}

\begin{abstract}
How to cite this paper: Diabate, M., Nimaga, D., Nindjin, C., Ahyi, V., Dossou, J. and Amani, N.G. (2019) Peroxide Index, Trans Fatty Acids, Acrylamide and Polycyclic Aromatic Hydrocarbons (Pah) Contents in Frying Oils and Fried Tuna Fish Involved in "Garba" Production in Côte d'Ivoire. Food and Nutrition Sciences, 10, 947-962.
\end{abstract}

https://doi.org/10.4236/fns.2019.108068

Received: March 20, 2019

Accepted: August 13, 2019

Published: August 16, 2019

Copyright $\odot 2019$ by author(s) and Scientific Research Publishing Inc. This work is licensed under the Creative Commons Attribution International License (CC BY 4.0).

http://creativecommons.org/licenses/by/4.0/ cc) (i) Open Access

\begin{abstract}
This current study aims at determining the profile and contents of degradation compounds produced during the interaction between the frying oils and tuna fish involved in the cooking of "Garba", a street food largely consumed in Côte d'Ivoire. For this purpose, the peroxide index and the neoformed compounds, especially trans fatty acids, acrylamid, polycyclic aromatic hydrocarbons were determined. This trial was carried out on 90 samples of frying oils and fried tuna fish collected from restaurant owners of "Garba" food in three locations in Abidjan. The samples were divided into three groups (G1, G2, and G3) according to the similarity of the practices adopted by the restorers. The results show that the peroxide values (14.95; 15.01 and 11.97 meqO $\mathrm{O}^{2} / \mathrm{kg}$ ) of the oils respectively for G2, G3, and G1 are higher than the values fixed by the Codex Alimentarius. The trans fatty acid contents of the frying oils were $56.80 \%$; $61.01 \%$ and $55.18 \%$ respectively for G3, G2 and G1. The average acrylamide content of fried Tuna $(69.43 \mu \mathrm{g} / \mathrm{kg})$ is higher than the value recorded in the cooking oil $(19.99 \mu \mathrm{g} / \mathrm{kg})$. The average contents of the eleven HAPs determined in the oils are higher than those of the Tuna. The Benzo (a) pyrene contents of both matrices are lower than the EU standard $1881 / 2011$ except for the G2 oil $(2.66 \mu \mathrm{g} / \mathrm{kg})$. Increased consumption of "Garba" may pose health risks to consumers as practices of frying Tuna generate compounds that are harmful to human health.
\end{abstract}




\section{Keywords}

Garba, Polycyclic Aromatic Hydrocarbons, Trans-Fatty Acids, Acrylamide

\section{Introduction}

These last years, street foods have created a special craze among people in Côte d'Ivoire especially in areas of strong demographic concentrations and important activities [1]. Among street foods, Garba is a ready-to-eat food made of fried tuna-fish, attiéké (cassava-based couscous), chopped pepper and edible vegetable oil [2]. Tuna-fish is mostly fried with refined palm oil and other oil whose quality is most of the time unknown [3]. The tuna-fish frying is carried out by immersion of the fish in a high quantity of vegetable oil at a high temperature varying from $160^{\circ} \mathrm{C}$ to $180^{\circ} \mathrm{C}$ [4] [5]. Frying is a process that enables improved sensory properties of food including aroma [6]. However, the frying process provokes oil deterioration because it requires high temperature and fast heat transfer [7] [8]. Indeed, the use of edible oil at high temperature induces degradation of major components, notably fatty acids which lead to oil oxydation, polymerisation, isomerisation and hydrolyse [9]. Moreover, the overuse of oil leads to the production of a rate of $10 \%$ to $40 \%$ of frying-induced compounds in fried oil during Garba production marketed in Abidjan [10]. These compounds which appear during heating can be absorbed by the fried products in permanent way. Polycyclic aromatic hydrocarbons (PAH), acrylamide and trans fatty acids are some of the toxic compounds newly produced during oil frying which have health adverses [11].

According to the World Health Organization, these newly frying-induced compounds or polar compounds could be responsible for cardiovascular diseases, cancer, and congenital malformations. Since these compounds represent a public health issue, settlements of maximal limits are required so that Garba plays an important role in Ivorian food habits. Hence, this study aims at evaluating the impact of frying fish practices on the quality of "Garba". Specifically, it aims to:

- the profile and contents of degradation compounds produced during the interaction between the frying oils and the tuna fish used in the production of "Garba" food in Côte d'Ivoire;

- evaluate the trans fatty acids content and the peroxide index value in fried oil;

- determinate acrylamide content of fried oil and fried tuna-fish;

- determine the Polycyclic aromatic hydrocarbons (PAH) content in fried tuna-fish and oil.

\section{Materials and Methods}

\subsection{Study Area}

During the current study, the sampling of frying oils and tuna fish were made in 
the District of Abidjan. It is a sub-Saharan nation in West Africa located at $5^{\circ} 19^{\prime} 0.001 " \mathrm{~N}, 4^{\circ} 1^{\prime} 59.999^{\prime \prime} \mathrm{W}$ (Figure 1).

Samples were collected from 90 restaurants of "Garba" in Abidjan. At the first step, the survey model was developed from the list of the municipality in Abidjan whose demographic data were found in the report of General Population and Housing Census [12]. 10 areas per municipality (Abobo, Cocody and Yopougon) were selected based on this list and the level of consumption of the Garba dish by the population (Figure 2). Finally, three restaurants were randomly selected in each (areas).

\subsection{Sampling}

A total of 90 samples of oil and fried tuna (Figure 3) were taken from the selected restaurants after the evaluation of the neoformed compounds contents (NF EN ISO 8420). For that, the Testo 270 device (Serial number 20388792 of the polychemy firm, Germany) was used.

Five pieces of fried tuna were randomly taken from the batch of fried fish intended for sale. Also, $45 \mathrm{ml}$ of frying oil was sampled. All the samples were wrapped with aluminum foil, labelled and sent to the laboratory using a cooler.

Based on a previous study on the practices adopted by restaurateurs for tuna

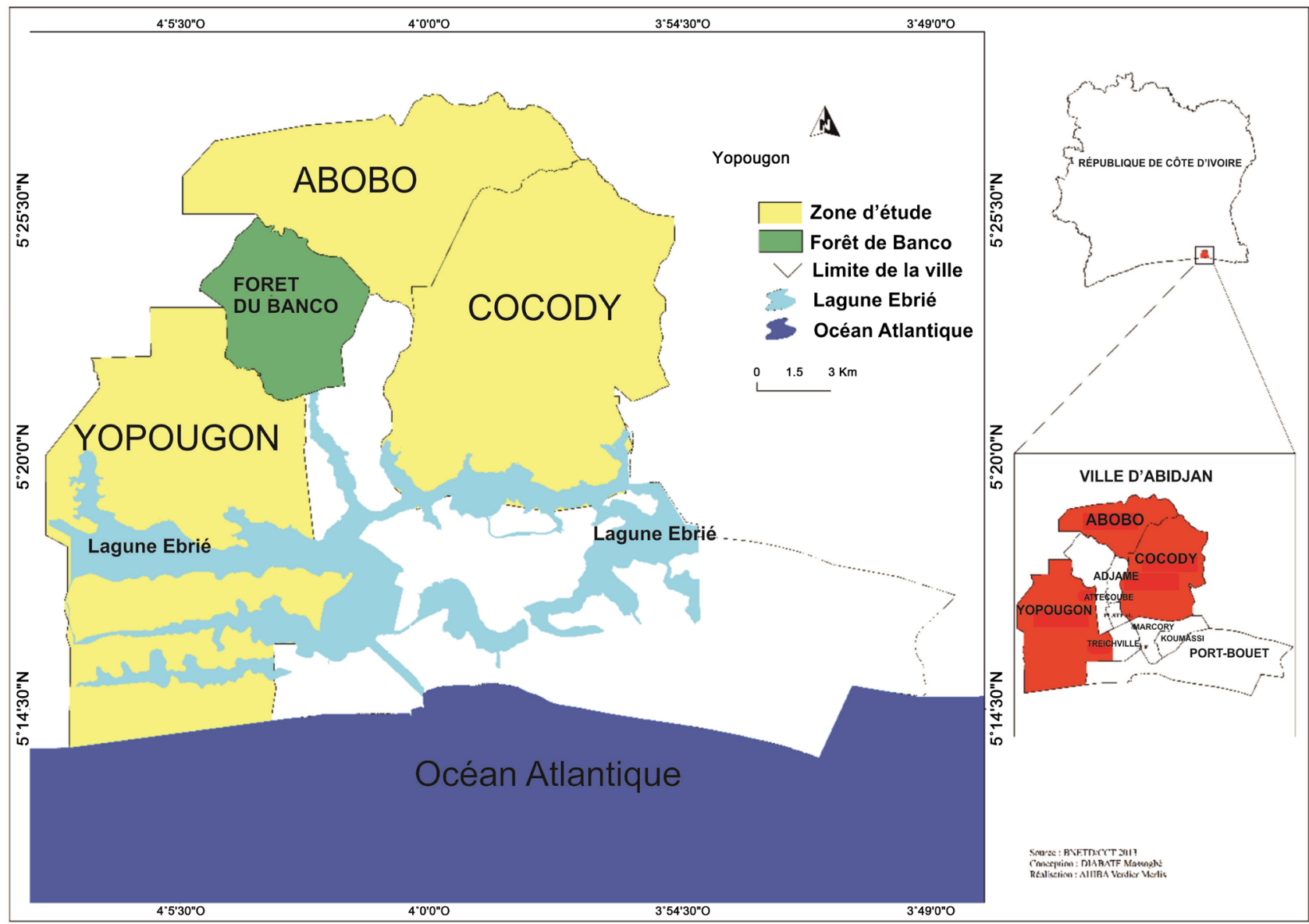

Figure 1. Map of the District of Abidjan showing the selected communes. 

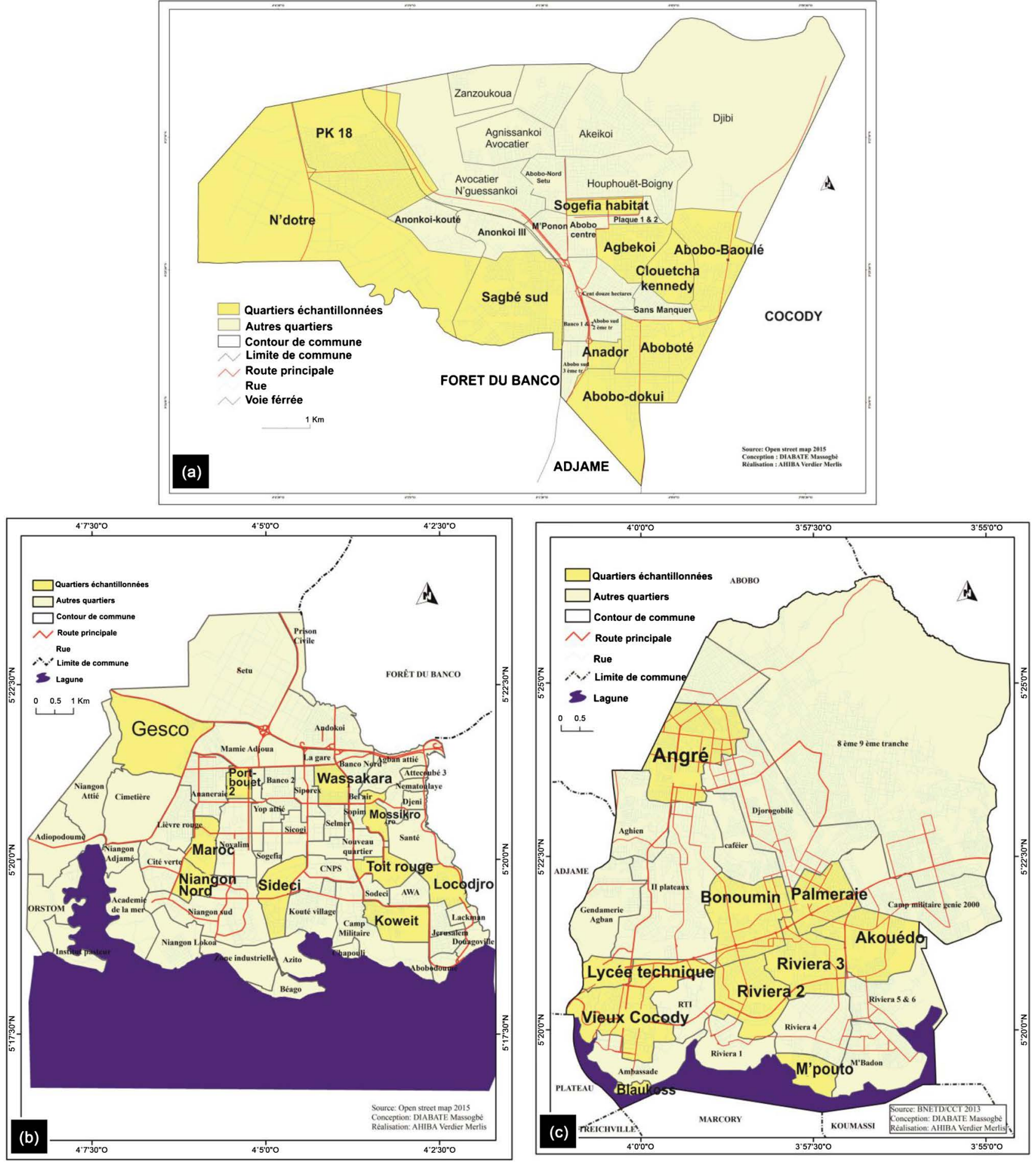

Figure 2. Study area. (a) Commune of Abobo; (b) Commune of Yopougon; (c) Commune of Cocody.

frying, three stable groups (G1, G2, G3) of restaurateurs were formed according to the similarity of frying practices adopted by restaurateurs in the three municipalities chosen.

Group 1 is characterized by restorers whose measured oils have the content of neoformed compounds of less than $25 \%$ for frying at frying temperatures below 


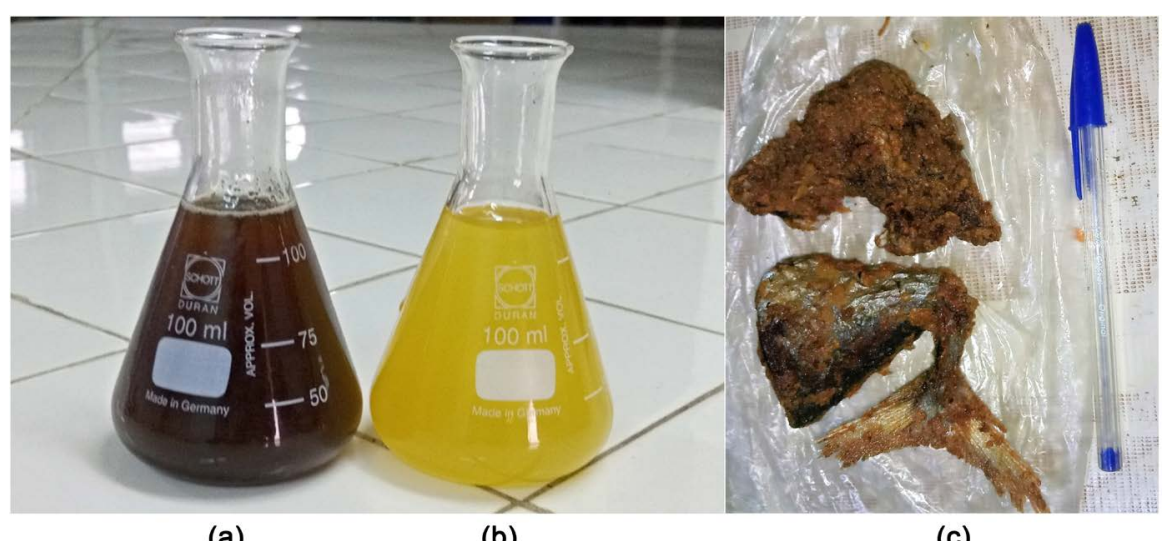

(a)

(b)

(c)

Figure 3. Photograph of sample oil and fish. (a) Reused oils sample; (b) New oils sample; (c) Deep-fried tuna sample.

$160^{\circ} \mathrm{C}$ for frying tuna for 6 to 10 minutes. The oil is used only three times before adding oil.

Group 2 includes all restorers whose reused oils contain neoformed compounds ranging from $25 \%$ to $30 \%$. Their frying temperatures are $160^{\circ} \mathrm{C}$ and the oil is reused 4 to 6 times before adding oil for frying tuna pieces 11 to 20 minutes during each use of the oil.

Group 3 is dominated by restorers whose oils contain more than $30 \%$ neoformed compounds. Their frying oils are reused until blackening before adding new oil at temperatures from $160^{\circ} \mathrm{C}$ to over $180^{\circ} \mathrm{C}$ for frying times of 11 to 20 minutes [10].

Fried oil samples were kept away from heat, light and moisture of room temperature, while fried tuna-fish samples were grounded and stored at $-18^{\circ} \mathrm{C}$ until chemical analysis.

\subsection{Analysis of Trans Fatty Acids in Frying Oil}

\subsubsection{Sample Preparation}

Analysis of trans fatty acids was made using the AOAC Official Method SM 996.06 and AOAC Official Method 969.33 [13]. Fatty acid methyl ester of the oil samples was prepared according to AOAC Official Method 969.33 [13]. $1 \mathrm{~g}$ homogenized sample was mixed with $2.0 \mathrm{~mL}$ ethanol. The entire product was dispersed in $10.0 \mathrm{~mL}$ of $8.3 \mathrm{M} \mathrm{HCl} .2 \mathrm{~mL}$ of triundecanoic acid ( $5 \mathrm{mg}$ triundecanoic acid in $1 \mathrm{~mL} \mathrm{CHCl}_{3}$ ) and used as the internal standard. The tubes were incubated for 60 minutes at $80^{\circ} \mathrm{C}$ in a water bath with intermittent mixing every 10 min. After digestion, the test tubes were allowed to cool at room temperature. 2 $\mathrm{mL}$ ethanol was added through the sides of the tube, mixed for 1 minute followed by $25 \mathrm{~mL}$ diethyl ether and again mixed for 5 minutes. $25 \mathrm{~mL}$ petroleum ether was added, mixed for 5 minutes and allowed to remain for 1 hour until the upper ether phase became clear. The upper phase was transferred into a $150 \mathrm{~mL}$ beaker and dried slowly under Nitro-gen stream. The extracted fat was weighed and transferred into a glass vial with $3 \mathrm{~mL}$ chloroform and $3 \mathrm{~mL}$ diethyl ether and dried again. $2 \mathrm{~mL}$ of $7 \%$ Boron trifluoride (BF3), methylating agent, and $1 \mathrm{~mL}$ to- 
luene were then added with intermittent mixing to the extracted fat and heated at $100^{\circ} \mathrm{C}$ for 45 minutes to convert the fat into fatty acid methyl esters (FAME). After methylation, $1 \mathrm{~g}$ sodium sulfate solution was added to remove moisture content. Esters were extracted with $1 \mathrm{~mL}$ hexane transferred into $2 \mathrm{~mL}$ vial (Teflon capped) and loaded on gas chromatography (GC) after appropriate dilutions.

\subsubsection{Gas Chromatographic Analysis}

The fatty acid methyl esters were run on gas chromatography (GC) which was equipped with a flame-ionization detector. Fused silica capillary cis/trans column SP 2560, $100 \mathrm{~m} \times 250 \mu \mathrm{m}$ internal diameters $\times 0.20 \mu \mathrm{m}$ film was used (Supelco, Belefonte, Pennsylvania).

The following temperature programme was used for optimal separation of fatty acids including trans fatty acids: initial oven temperature was $140^{\circ} \mathrm{C}$, hold time was 5 minutes; ramp $1^{\circ} \mathrm{C} / \mathrm{min}$; the final temperature was $250^{\circ} \mathrm{C}$; hold time was 25 minutes, and total run time was 120 minutes. Injector port was $225^{\circ} \mathrm{C}$; Detector port was $260^{\circ} \mathrm{C}$; and the gas rates used were $0.3 \mathrm{~mL} / \mathrm{min}$ carrier gas (Nitrogen), $15 \mathrm{~mL} / \mathrm{min}$ make up gas (Nitrogen) and 35 and $350 \mathrm{~mL} / \mathrm{min}$ flame gases hydrogen and air, respectively. A split ratio of 1:10 and an injection volume of $1 \mu \mathrm{l}$ were used. The fatty acid composition was determined by comparing their retention times with those of known standards (fatty acid methyl esters from SUPELCO). Each peak was quantified by calculating the area under the peak using software from AIMIL (Nucon Technologies). The concentration of individual fatty acid was expressed as a percentage of total area under the peak. Samples were separately analyzed in triplicate. Trans fatty acid was expressed as $\mathrm{g} / 100 \mathrm{~g}$ food.

\subsection{Determination of PAH Profiles by GC-MS/MS in Frying Oil and Fried Tuna Fish}

An analytical method based on gas chromatography/tandem mass spectrometry (GC-MS/MS) (triple quadrupole device) was performed according to the method developed by [14] to quantity polycyclic aromatic hydrocarbons (PAHs) in fried Tuna fish and frying oil. After dilution of a test sample of $2 \mathrm{~g}$ of vegetable oil and $2 \mathrm{~g}$ fried fish in $2 \mathrm{~mL}$ of $\mathrm{n}$-hexane containing approximately $0.1 \mathrm{mg}$ of octadecane (C18), the solutions eluted on a column of $30 \mathrm{~g}$ of high purity silica with $150 \mathrm{~mL}$ of $\mathrm{n}$-hexane to isolate the hydrocarbon fraction. After evaporation of the solvent, the extract was taken up in $1 \mathrm{~mL}$ of isooctane and then the determination was carried out by gas chromatography (GC) with a capillary injector $15 \mathrm{~m}$ stationary phase. The temperature of the ionization detector was set at $380^{\circ} \mathrm{C}$. The temperature of the oven temperature that varied from $100^{\circ} \mathrm{C}$ to $370^{\circ} \mathrm{C}$ to $20^{\circ} \mathrm{C} /$ min allowed the rapid elimination of mineral oils and facilitated the integration of the chromatographic envelope.

\subsection{Determination of Acrylamide Content and Peroxide Index}

The acrylamide in the samples of oils and fish was determined by isotopic dilu- 
tion chromatography with mass spectrometric detection (LC-MS-MS analysis) as described by [15]. This LC-MS-MS analysis of acrylamide was performed with an Agilent 1100 high-performance liquid chromatography (HPLC) system (Santa Clara, CA, USA) consisting of a quaternary pump, an autosampler and a temperature-controlled column oven, coupled with an Agilent 1100 MS detector equipped with an electrospray ionization interface. The analytical column was a Kinetex C18 column $(100 \times 4.6 \mathrm{~mm}, 2.6 \mu \mathrm{m}$ particle size $)$ from Phenomenex (Torrance, CA, USA). The mobile phase was acetonitrile and 1/1000 formic acid aqueous solution $(30: 70, \mathrm{v} / \mathrm{v})$ with a flow-rate of $0.2 \mathrm{~mL} / \mathrm{min}$. The temperature of the column was kept at $25^{\circ} \mathrm{C}$. Data acquisition was performed, with a delay time of $8 \mathrm{~min}$, in a selected ion-monitoring (MRM) mode using the following interface parameters: a drying gas $(\mathrm{N} 2,665 \mathrm{~Pa})$ flow of $11 \mathrm{~L} / \mathrm{min}$, nebulizer pressure of $300 \mathrm{~Pa}$, drying gas temperatures of $350^{\circ} \mathrm{C}$, a capillary voltage of $11 \mathrm{kV}$ and a fragmenter voltage of $40 \mathrm{eV}$.

The peroxide index in oil samples was determined according to the method described by International Union of Pure and Applied Chemistry.

\subsection{Statistical Analysis}

The physico-chemical characterization data were analyzed for variance using the general linear model of the Statistical Analysis System software (SAS version 9.2). The contents trans fatty acids and peroxide value, acid value in oils were subjected to a one-factor ANOVA (oil sample group), PAHs and acrylamides were subjected to a two-factor ANOVA (analytical samples and sample groups). The Student Newman-Keuls test at the 5\% was used for the comparison of averages. Then, a correlation was performed using MINITAB 14 software. The Pearson correlation coefficient was determined between the different acrylamide and $\mathrm{PAH}$ contents in the oils of the groups formed. The significant difference was accepted when $\mathrm{P}<0.05$.

\section{Results}

\subsection{Variability of Trans Fatty Acids Content and Peroxide, Index of Frying Oils}

The trans fatty acids content and peroxide index of frying oils vary according to the groups $(\mathrm{p}<0.05$; Table 1$)$. Indeed, the highest linoelaidic acid content $(6.92 \%)$ of oils was recorded in the group G3 characterized by fried oil used until blackening, containing newly frying-induced compounds rate from $25 \%$ to $75 \%$. Frying temperature ranged between $160^{\circ} \mathrm{C}$ and over $180^{\circ} \mathrm{C}$ with fish cooking duration ranging between 6 and $10 \mathrm{~min}(\mathrm{p}<0.05$; Table 1$)$, while the lowest value (6.14\%) was recorded in the group G1 composed of re-used oil (4 - 6 times) heat at $180^{\circ} \mathrm{C}$ during $11-15 \mathrm{~min}$ and containing newly frying-induced compounds rate over than $25 \%$.

On the other hand, vaccenic acid content and total trans fatty acids rate of the group G2 were significantly $(P<0.05)$ higher than values found in both $\mathrm{G} 1$ and 
G3 groups. The peroxide index varies between $11.97 \%$ and $15.01 \%$ with the highest value found in $\mathrm{G} 3(\mathrm{P}<0.05)$.

\subsection{Acrylamide Content of Frying Oil and Fried Tuna-Fish}

Table 2 shows the variation of acrylamide content of fried tuna-fish and frying oil according to the group. The acrylamide concentration in frying oil fluctuates between $15.69 \mu \mathrm{g} / \mathrm{kg}$ and $25.50 \mu \mathrm{g} / \mathrm{kg}$ while in fried tuna-fish it ranges from $62.90 \mu \mathrm{g} / \mathrm{kg}$ to $78.29 \mu \mathrm{g} / \mathrm{kg}$. For both fried tuna-fish and frying oil, the G2 had recorded the highest concentration of acrylamide $(P<0.05)$. Significant differences in acrylamide content $(P<0.05)$ are recorded among groups $(G 1, G 2$ and G3) of fried tuna-fish and frying oil. Indeed, acrylamide content of fried tuna-fish is significantly $(\mathrm{P}<0.05)$ higher than the concentration recorded in frying oil considering the three groups and their average value.

\subsection{Variations of Polycyclic Aromatic Hydrocarbons (PAH) Content in Frying Oil and Tuna-Fish by Group}

$\mathrm{PAH}$ level recorded in frying oil and fried tuna-fish is given in Table 3 . The

Table 1. Trans fatty acids content and peroxide index value in frying oil.

\begin{tabular}{ccccc}
\hline Groups & Linoelaïdic acid (\%) & Vaccenic acid (\%) & $\begin{array}{c}\text { Total trans fatty } \\
\text { acids (\%) }\end{array}$ & $\begin{array}{c}\text { Peroxide index } \\
\left(\mathrm{méqO}^{2} / \mathrm{kg}^{2}\right.\end{array}$ \\
\hline G1 & $6.14 \pm 0.13^{\mathrm{a}}$ & $48.26 \pm 0.84^{\mathrm{b}}$ & $55.18 \pm 0.88^{\mathrm{b}}$ & $11.97 \pm 1.12^{\mathrm{b}}$ \\
G2 & $6.83 \pm 0.16^{\mathrm{b}}$ & $54.87 \pm 2.33^{\mathrm{a}}$ & $61.01 \pm 2.41^{\mathrm{a}}$ & $14.95 \pm 0.89^{\mathrm{a}}$ \\
G3 & $6.92 \pm 0.18^{\mathrm{a}}$ & $49.97 \pm 0.98^{\mathrm{b}}$ & $56.80 \pm 0.92^{\mathrm{b}}$ & $15.01 \pm 1.125^{\mathrm{a}}$ \\
Group Effect & $* * *$ & $* * *$ & $* * *$ & $* * *$ \\
\hline
\end{tabular}

${ }^{* * *}: \mathrm{P}<0.001$; SE: Standard Error; The Mean \pm SE followed by the same letter in the same column are not significantly different from P > 0.05. G1: group 1; G2: group 2; G3: group 3. The capital letters were used to compare average of three groups.

Table 2. Acrylamide content in fried tuna-fish and frying oil.

\begin{tabular}{ccc}
\hline Samples & Groups & Acrylamide content $(\mu \mathrm{g} / \mathrm{kg})$ \\
\hline Fried oil & G1 & $15.69 \pm 0.01^{\mathrm{a}}$ \\
& G2 & $25.50 \pm 0.01^{\mathrm{b}}$ \\
& G3 & $19.30 \pm 0.01^{\mathrm{c}}$ \\
& Average & $19.99 \pm 1.35^{\mathrm{B}}$ \\
\hline Fried tuna-fish & G1 & $62.90 \pm 0.01^{\mathrm{b}}$ \\
& G2 & $78.29 \pm 0.03^{\mathrm{a}}$ \\
& G3 & $67.10 \pm 0.01^{\mathrm{c}}$ \\
& Average & $69.43 \pm 2.29^{\mathrm{A}}$
\end{tabular}

\section{Group effect}

$* * *$

${ }^{* *}: \mathrm{P}<0.001$; SE: Standard Error; The Mean \pm SE followed by the same letter in the same column are not significantly different from P > 0.05. G1: group 1; G2: group 2; G3: group 3. The capital letters were used to compare average of three groups. 
Table 3. PAH concentration in frying oil and fried tuna-fish.

\begin{tabular}{|c|c|c|c|c|c|c|c|c|c|c|c|c|}
\hline \multirow{2}{*}{ 芯 } & \multirow[b]{2}{*}{ Groups } & \multicolumn{11}{|c|}{ PAH concentrations $(\mu \mathrm{g} / \mathrm{kg})$} \\
\hline & & $\begin{array}{c}\text { Benzo (a) } \\
\text { anthracene }\end{array}$ & $\begin{array}{c}\text { Benzo (b) } \\
\text { fluoranthene }\end{array}$ & $\begin{array}{c}\text { Benzo (a) } \\
\text { pyrene }\end{array}$ & Chrysene & Anthracene & $\begin{array}{c}\text { Benzo (k) } \\
\text { fluorantene }\end{array}$ & $\begin{array}{c}\text { Benzo (j) } \\
\text { fluoranthene }\end{array}$ & $\begin{array}{c}\text { Benzo } \\
(j . h . i) \\
\text { perylene }\end{array}$ & $\begin{array}{c}\text { Dibenz } \\
\text { (a.h) } \\
\text { anthracene }\end{array}$ & Fluoranthene & $\begin{array}{c}\text { Indeno } \\
(1.2 .3 .-\mathrm{cd}) \\
\text { pyrene }\end{array}$ \\
\hline \multirow{5}{*}{ 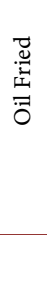 } & G1 & $1.34 \pm 0.10^{c}$ & $1.24 \pm 0.09^{\mathrm{c}}$ & $1.48 \pm 0.11^{\mathrm{c}}$ & $1.26 \pm 0.09^{c}$ & $1.09 \pm 0.08^{c}$ & $1.13 \pm 0.08^{\mathrm{c}}$ & $1.36 \pm 0.10^{c}$ & $1.22 \pm 0.09^{c}$ & $1.35 \pm 0.10^{\mathrm{c}}$ & $1.17 \pm 0.08^{c}$ & $1.38 \pm 0.10^{c}$ \\
\hline & G2 & $1.97 \pm 014^{\mathrm{a}}$ & $1.84 \pm 0.13^{\mathrm{a}}$ & $2.66 \pm 0.19^{a}$ & $1.82 \pm 0.13^{\mathrm{a}}$ & $1.80 \pm 0,13^{\mathrm{a}}$ & $1.92 \pm 0.14^{\mathrm{a}}$ & $1.85 \pm 0.13^{\mathrm{a}}$ & $1.85 \pm 0.13^{\mathrm{a}}$ & $1.95 \pm 0.14^{\mathrm{a}}$ & $1.96 \pm 0.14^{\mathrm{a}}$ & $1.94 \pm 0.14^{\mathrm{a}}$ \\
\hline & G3 & $1.44 \pm 0.10^{\mathrm{b}}$ & $1.39 \pm 0.10^{\mathrm{b}}$ & $1.85 \pm 0.13^{\mathrm{b}}$ & $1.31 \pm 0.09^{\mathrm{b}}$ & $1.25 \pm 0.09^{b}$ & $1.37 \pm 0.10^{\mathrm{b}}$ & $1.53 \pm 0.11^{\mathrm{b}}$ & $1.34 \pm 0.10^{\mathrm{b}}$ & $1.46 \pm 0.01^{\mathrm{b}}$ & $1.26 \pm 0.09^{\mathrm{b}}$ & $1.57 \pm 0.11^{b}$ \\
\hline & Average & $1.58 \pm 0.11^{\mathrm{c}}$ & $1.49 \pm 0.11^{\mathrm{A}}$ & $2.002 \pm 0.14^{\mathrm{A}}$ & $1.46 \pm 0.10^{\mathrm{A}}$ & $1.38 \pm 0.10^{\mathrm{A}}$ & $1.47 \pm 0.11^{\mathrm{A}}$ & $1.58 \pm 0.11^{\mathrm{A}}$ & $1.50 \pm 0.11^{\mathrm{A}}$ & $1.58 \pm 0.10^{\mathrm{A}}$ & $1.46 \pm 0.10^{\mathrm{A}}$ & $1.63 \pm 0.12^{\mathrm{A}}$ \\
\hline & G1 & $0.89 \pm 0.20^{c}$ & $0.87 \pm 016^{c}$ & $0.80 \pm 0.20^{c}$ & $1.06 \pm 0.18^{c}$ & $0.73 \pm 0.16^{\mathrm{c}}$ & $0.78 \pm 0.15^{\mathrm{c}}$ & $0.91 \pm 0.20^{c}$ & $0.81 \pm 0.18^{c}$ & $0.88 \pm 0.20^{c}$ & $0.76 \pm 0.18^{c}$ & $0.94 \pm 0.19^{c}$ \\
\hline \multirow{2}{*}{ 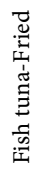 } & G2 & $1.51 \pm 0.20^{\mathrm{a}}$ & $1.39 \pm 0.20^{\mathrm{a}}$ & $1.96 \pm 0.31^{\mathrm{a}}$ & $1.33 \pm 0.21^{\mathrm{a}}$ & $1.36 \pm 0.19^{\mathrm{a}}$ & $1.40 \pm 0.23^{\mathrm{a}}$ & $1.47 \pm 0.16^{\mathrm{a}}$ & $1.46 \pm 0.21^{\mathrm{a}}$ & $1.46 \pm 0.22^{\mathrm{a}}$ & $1.43 \pm 0.23^{\mathrm{a}}$ & $1.47 \pm 0.20^{\mathrm{a}}$ \\
\hline & Average & $0.70 \pm 0.08^{\mathrm{B}}$ & $0.67 \pm 0.06^{\mathrm{B}}$ & $0.89 \pm 0.09^{\mathrm{B}}$ & $0.56 \pm 0.07^{\mathrm{B}}$ & $0.62 \pm 0.0^{\mathrm{B}}$ & $0.61 \pm 0.06^{\mathrm{B}}$ & $0.73 \pm 0.09^{\mathrm{B}}$ & $0.66 \pm 0.08^{\mathrm{B}}$ & $0.64 \pm 0.08^{\mathrm{B}}$ & $0.60 \pm 0.07^{\mathrm{B}}$ & $0.73 \pm 0.07^{\mathrm{B}}$ \\
\hline \multicolumn{2}{|c|}{ Group effect } & $* * *$ & $* * *$ & $* * *$ & $* * *$ & $* * *$ & $* * *$ & $* * *$ & $* * *$ & $* * *$ & $* * *$ & $* * *$ \\
\hline
\end{tabular}

***: P < 0.001; The Mean \pm SE followed by the same letter in the same column are not significantly different from P > 0.05. G1: group 1; G2: group 2; G3: group 3. The capital letters were used to compare average of three groups.

concentration of benzo(a)pyrene $(\mathrm{BaP})$, determined in frying oil, ranges from $1.48 \pm 0.11 \mu \mathrm{g} / \mathrm{kg}$ to $2.66 \pm 0.19 \mu \mathrm{g} / \mathrm{kg}$. While in fried tuna-fish, BaP concentration ranges from $0.80 \pm 0.20 \mu \mathrm{g} / \mathrm{kg}$ and $1.96 \pm 0.31 \mu \mathrm{g} / \mathrm{kg}$. In frying oil, the highest contents in Benzo(a) anthracene, Benzo(b) fluoranthène, Benzo(a) pyrene, Chrysène, Anthracène, Benzo $(k)$ fluorantène, Benzo(j), fluoranthène, Benzo(j.h.i)pérylène, Dibenz(a.h) anthracene, Fluoranthène, Indeno(1.2.3.-cd)pyrene were found in the oils of the group G2 characterized by frying oil used until blackening, containing newly frying-induced compounds rate between $25 \%$ and $75 \%$. Frying temperature ranged between $160^{\circ} \mathrm{C}$ and over $180^{\circ} \mathrm{C}$ with fish cooking duration ranging between 6 and 10 mins. The lowest contents in Benzo(a) anthracene, Benzo(b) fluoranthène, Benzo(a) pyrene, Chrysène, Anthracène, $\operatorname{Benzo}(k)$ fluorantène, Benzo(j), fluoranthène, Benzo(j.h.i)pérylène, Dibenz(a.h) anthracene, Fluoranthène, Indeno(1.2.3.-cd)pyrene were recorded in the oils of the group G1 $(\mathrm{P}<0.05)$. This group gathers oils characterized by newly frying-induced compounds rate. Less than $25 \%$ of their heating temperatures are below $160^{\circ} \mathrm{C}$; the frying duration is about $5 \mathrm{~min}$, and the frequency of re-used is 3 times before addition of fresh oil.

In fried Tuna fish, the same trend was observed. Samples of the group G1 have the highest PAH concentration while G3 samples have lower PAH concentration for frying oil as well as fried tuna-fish $(\mathrm{P}<0.05)$.

\subsection{Relationship between Acrylamide Content and PAH Concentrations of Frying Oil and Fried Tuna-Fish}

The relationships between acrylamide content and PAH concentrations of frying oil and fried tuna-fish are given in Table 4. It appears that Anthracene content in the frying oil was strongly and positively associated $(0.96 \leq \mathrm{r} \leq 0.99$; $\mathrm{P}<$ 
Table 4. Relationship between acrylamide content and PAH concentrations of frying oil and fried tuna-fish.

\begin{tabular}{|c|c|c|c|c|c|c|c|c|c|c|c|c|c|c|}
\hline Variables & 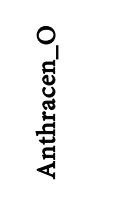 & 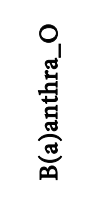 & 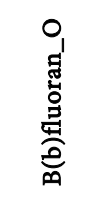 & 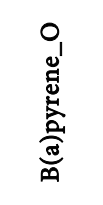 & 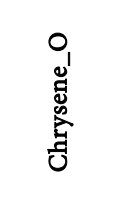 & 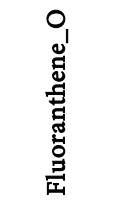 & 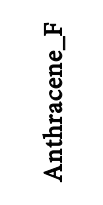 & 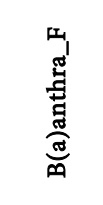 & 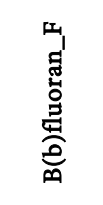 & 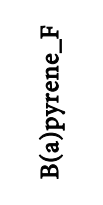 & 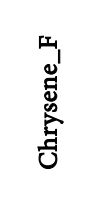 & 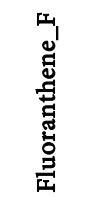 & 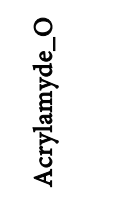 & 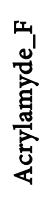 \\
\hline Anthracene_O & 1 & & & & & & & & & & & & & \\
\hline B(a)anthra_O & $0.99^{* * *}$ & 1 & & & & & & & & & & & & \\
\hline $\mathrm{B}(\mathrm{b})$ fluoran_O & $0.99^{* * *}$ & $0.99^{* * *}$ & 1 & & & & & & & & & & & \\
\hline $\mathrm{B}(\mathrm{a})$ pyrène_O & $0.99^{* * *}$ & $0.98^{* * *}$ & $0.99^{* * *}$ & 1 & & & & & & & & & & \\
\hline Chrysene_O & $0.99^{* * *}$ & $0.99^{* * *}$ & $0.98^{* * *}$ & $0.97^{* * *}$ & 1 & & & & & & & & & \\
\hline Fluoranthene_O & $0.99^{* * *}$ & $0.99^{* * *}$ & $0.99^{* * *}$ & $0.98^{* * *}$ & $0.99^{* * *}$ & 1 & & & & & & & & \\
\hline Anthracene_F & $0.98^{* * *}$ & $0.97^{* * *}$ & $0.98^{\star * *}$ & $0.99^{* * *}$ & $0.95^{\star * *}$ & $0.96^{* * *}$ & 1 & & & & & & & \\
\hline B(a)anthra_F & $0.99^{* * *}$ & $0.98^{* * *}$ & $0.99^{* * *}$ & $0.99^{* * *}$ & $0.97^{* * *}$ & $0.97^{* * *}$ & $0.99^{* * *}$ & 1 & & & & & & \\
\hline $\mathrm{B}(\mathrm{b})$ fluoran_F & $0.99^{* * *}$ & $0.99^{* * *}$ & $0.99^{* * *}$ & $0.98^{* * *}$ & $0.99^{* * *}$ & $0.99^{* * *}$ & $0.97^{* * *}$ & $0.98^{\star * *}$ & 1 & & & & & \\
\hline B(a)pyrene_F & $0.99^{* * *}$ & $0.99^{* * *}$ & $0.99^{* * *}$ & $0.99^{* * *}$ & $0.98^{* * *}$ & $0.98^{* * *}$ & $0.99^{* * *}$ & $0.99^{* * *}$ & $0.99^{* * *}$ & 1 & & & & \\
\hline Chrysene_F & $0.99^{* * *}$ & $0.99^{* * *}$ & $0.99^{* * *}$ & $0.99^{* * *}$ & $0.98^{* * *}$ & $0.98^{* * *}$ & $0.99^{* * *}$ & $0.99^{* * *}$ & $0.99^{* * *}$ & $0.99^{* * *}$ & 1 & & & \\
\hline Fluoranthène_F & $0.99^{* * *}$ & $0.98^{* * *}$ & $0.99^{* * *}$ & $0.99^{* * *}$ & $0.96^{* * *}$ & $0.97^{* * *}$ & $0.99^{* * *}$ & $0.99^{* * *}$ & $0.98^{* * *}$ & $0.99^{* * *}$ & $0.99^{* * *}$ & 1 & & \\
\hline Acrylamyde_O & $0.08^{\mathrm{NS}}$ & $0.02^{\mathrm{NS}}$ & $0.11^{\mathrm{NS}}$ & $0.18^{\mathrm{NS}}$ & $-0.052^{\mathrm{NS}}$ & $-0.01^{\mathrm{NS}}$ & $0.26^{\mathrm{NS}}$ & $0.19^{\mathrm{NS}}$ & $0.04^{\mathrm{NS}}$ & $0.13^{\mathrm{NS}}$ & $0.15^{\mathrm{NS}}$ & $0.22^{\mathrm{NS}}$ & 1 & \\
\hline Acrylamyde_F & $-0.044^{\mathrm{NS}}$ & $-0.11^{\mathrm{NS}}$ & $-0.02^{\mathrm{NS}}$ & $0.06^{\mathrm{NS}}$ & $-0.18^{\mathrm{NS}}$ & $-0.15^{\mathrm{NS}}$ & $0.13^{\mathrm{NS}}$ & $0.06^{\mathrm{NS}}$ & $-0.08^{\mathrm{NS}}$ & $0.01^{\mathrm{NS}}$ & $0.02^{\mathrm{NS}}$ & $0.09^{\mathrm{NS}}$ & $0.992^{* * *}$ & 1 \\
\hline
\end{tabular}

NS: $\mathrm{P}>0.05$ (Non-Significant); ${ }^{* *}$ : $\mathrm{P}<0.001$. Anthracene_O: Anthracene content in the frying oil; B(a)anthra_O: B(a)Anthracene content in the frying oil; B(b)fluoran_O: B(b) Fluoranthene content in the frying oil; B(a)pyrene_O: B(a) pyrene content in the frying oil; Chrysene: Chrysene content in the frying oil; Fluoranthene_O: Fluoranthene content in the frying oil; Anthracene_F: Anthracene content in the fried fish; B(a)anthra_F: B(a)Anthracene content in the fried fish; B(b)fluoran_F: B(b) Fluoranthene content in the fried fish; B(a)pyrene_F: B(a) pyrene content in the fried fish; Chrysene_F: Chrysene content in the fried fish; Fluoranthene_F: Fluoranthene content in the fried fish; Acrylamyde_O: Acrylamyde content in the frying oil; Acrylamyde_F: Acrylamyde content in the fried fish.

0.001) with:

- the Anthracene content in the fried fish;

- B(a)Anthracene content in the fried fish;

- B(b) Fluoranthene content in the fried fish;

- $\mathrm{B}(\mathrm{a})$ pyrene content in the fried fish;

- Chrysene content in the fried fish;

- Fluoranthene content in the fried fish;

- B(a)Anthracene content in the frying oil;

- B(b) Fluoranthene content in the frying oil;

- $\mathrm{B}(\mathrm{a})$ pyrene content in the frying oil;

- Chrysene content in the frying oil;

- and Fluoranthene content in the frying oil.

Similarly, B(a)Anthracene content in the frying oil; B(b)Fluoranthene content in the frying oil; $\mathrm{B}(\mathrm{a})$ pyrene content in the frying oil and Chrysene content in the frying oil were also strongly and positively associated $(0.96 \leq \mathrm{r} \leq 0.99$; $\mathrm{P}<$ 0.001) with:

- the Anthracene content in the fried fish; 
- $\mathrm{B}(\mathrm{a})$ Anthracene content in the fried fish;

- $\mathrm{B}(\mathrm{b})$ Fluoranthene content in the fried fish;

- B(a)pyrene content in the fried fish;

- Chrysene content in the fried fish;

- Fluoranthene content in the fried fish and $\mathrm{B}(\mathrm{a})$ Anthracene content in the frying oil; $\mathrm{B}(\mathrm{b})$.

Furthermore, Acrylamyde content in the frying oil was strongly and positively associated $(\mathrm{r}=0.99 ; \mathrm{P}<0.001)$ with the Acrylamyde content in the fried fish. However, any significant correlation wasn't found between Acrylamyde content in the frying oil and the different PAH concentrations of frying oil and fried tuna-fish.

\section{Discussion}

The peroxide number and acid number values determined for the three groups are higher than the standard values set by the codex alimantarius, which are respectively $10 \mathrm{meqO} / \mathrm{kg}$ and $0.6 \mathrm{mg} \mathrm{KOH} / \mathrm{g}$ for the consumption oil [16]. These high oil index values could reflect the deteriorating state of the oils, which are mainly used to fry tuna in the "Garba". This deterioration would come from the initial quality of the oils, most often of an unknown nature, or from different practices such as the application of temperatures from $160^{\circ} \mathrm{C}$ to $180^{\circ} \mathrm{C}$, numerous reuses, but also from the frying environment. Indeed, the restaurateurs of this dish adopt the practice of overusing oil with oil additions during frying with traditional open fryers [10]. This common practice in gargotes according to [17], of continuous and repeated use of frying oil is adopted to reduce restaurant owners' expenses. However, the oil is subject to high heat, oxygen (from air or food) and moisture (from food) for long periods of frying time, resulting in a complex series of oxidation, hydrolysis, isomerization and polymerization reactions [18] [19]. These reactions lead to a deterioration of the initial composition of the oil (Brühl, 2014) and the subsequent generation of a wide variety of volatile and non-volatile compounds [20], which eventually modify the sensory, nutritional and functional properties of the oil (Crosa et al., 2014). Since foods absorb a remarkable amount of oil during frying, making frying oil a component of the frying product [21] [22], oil degradation will then have negative effects on the sensory properties of fried foods [23] [24] but also on consumer health [25] [26], hence the quantification of three new compounds, trans fatty acids, acrylamide and PAHs in both reused oils and fried tuna, of the total share of measured polar substances for better health risk assessment. In addition, the higher the frying temperature, the more atypical fatty acids and new toxic compounds are formed under the influence of heat, which degrades the quality of the oil over time during the many reuses. The levels of trans fatty acids, polycyclic aromatic hydrocarbons and acrylamide quantified in frying oils and fried tuna in "Garba" dishes throughout the study area are significant. The trans fatty acid content of the oil in the three practice groups exceeds $1 \%$ of the tolerable trans fatty acids 
for consumption according to the World Health Organization. Health problems such as heart attack, the development of components of the metabolic syndrome and diabetes may occur in people whose diets are high in trans fatty acids [27] [28] [29]. Indeed, numerous intervention or epidemiological studies in humans have shown that the increase in trans fatty acid consumption was correlated with the increase in cardiovascular risk factors. For high levels of intake, trans fatty acids increase LDL cholesterol as do saturated fatty acids, but trans fatty acids also tend to lower HDL cholesterol. Based on some results reported in the literature, also a threshold of $1.3 \%$ to $3 \%$ of trans fatty acid consumed as a proportion of total energy can be safe.

An analysis of several studies (meta-analysis) on influence of the level of trans C18:1 consumption (expressed as a $\%$ of total energy intake) compared to oleic acid (C18:1 cis), shows a dose-response effect with LDL-C and to a lesser extent about $1 \%$ of total energy intake with HDL cholesterol.

Also, the high levels of acrylamide quantified in fried tuna are believed to be due to the sprinkling of manioc and wheat flour on fish by the majority of restaurateurs in the "Garba" before frying. These flours made of simple sugar (glucoses, fructoses, etc.) in addition to asparagine (protein) contained in tuna are precursors to acrylamide, which appears at temperatures around $120^{\circ} \mathrm{C}$ during frying [30] [31]. During frying, the Maillard reaction is the main reaction affecting sugars and proteins. The high acrylamide contents quantified in the fried tunas of the three groups formed would also come from the application of high temperature for frying. In fact, in a study by Miao et al. in 2013, it was shown that temperature increases during long cooking times of potato chips increased acrylamide levels in the food as a result. However, acrylamide values in fried tuna samples from all groups in this study are lower than those determined in chips $(786.3 \mu \mathrm{g} / \mathrm{kg})$, cookies $(389.5 \mu \mathrm{g} / \mathrm{kg})$, bread $(84.4 \mu \mathrm{g} / \mathrm{kg})$ also heat treated by frying in other studies [32]. However, the acrylamide values of the reuitized oil samples are in perfect agreement with those found in almonds and some seeds that also varied from 15 to $60 \mu \mathrm{g} / \mathrm{kg}$ [33]. The ingestion of acrylamide via food may expose us to the risk of cancer because, after several studies in animals, a carcinogenic effect has been observed. The International Agency for Research on Cancer (IARC) has therefore classified acrylamide as "probably neurotoxic, genotoxic and carcinogenic to humans" [34].

In addition, the observation by restaurateurs in the "Garba" of the application of very high temperatures that are difficult to control for frying tuna with rudimentary equipment should be at the origin of quantified PAHs [3]. The BaP contents and the sum of the contents of Benzo(a)anthracene, Benzo(b)fluoranthene, Benzo(a)pyrene and Chrysene quantified in frying oils and fried tuna for the three groups are below the maximum limit of $2 \mu \mathrm{g} / \mathrm{Kg}$ for B(a)P and $10 \mu \mathrm{g} / \mathrm{Kg}$ respectively for the sum of the four PAHs (European Commission EC No 1881/2011 for oils and fats intended for direct consumption). However, the low levels of polycyclic aromatic hydrocarbons in both types of samples should still 
be preoccupying because these bioaccumulative substances in the body are carcinogenic [35]. The observed possitive correlation between acrylamide and PAHs of frying oils and fried tunas could confirm their membership in the total proportion of neoformed substances in the oil.

\section{Conclusion}

In the light of this work, it was noted that trans fatty acid, acrylamide and 11 PAHs were present in the sampled reused frying oils and fried tuna from the "Garba" dish. The contents of the different quantified PAHs in the samples of the three groups (G1, G2, G3) are very low but not negligible because they are likely to bioaccumulate. On the other hand, high levels of trans fatty acids and acrylamide have been quantified. In addition, the peroxide and acid indices of the oils reused for the many frying cycles are generally high. The oils collected from group G1 and G2 conservators reusing the oil at high temperatures contain the highest values of the three substances, the acid number and the peroxide number. The health risk assessment approach of this study made it possible to estimate exposures, hazard quotient, hazard index related to quantified substances in reused oils and fried tuna from the "Garba" marketed in Abidjan. Exposure to neoformed compounds has been estimated. Increased consumption of this meal could have consequences for the health of consumers because the meal contains substances known to be harmful. In addition, this theoretical study to assess the health risk associated with the consumption of fried tuna and reused oils revealed a cancer risk from acrylamide and Benzo(a)pyrene. It is therefore important to ensure that good practices in the use of oils are monitored and applied to improve the quality of fried tuna and preserve the quality of the oil during the many frying cycles. This is why, in chapter three, an optimization of the parameters influencing the frying process will be carried out.

\section{Acknowledgements}

This research has been supported by the International Foundation for Science (IFS), Sweden, through a research grant ( $\mathrm{N}^{\circ}$.E/5397-1, 2013-06-19) awarded to Mr Daouda NIMAGA. The authors thank Nangui Abrogoua University (Abidjan, Côte d'Ivoire) and the government of the Republic of Côte d'Ivoire for all supports during this research.

\section{Conflicts of Interest}

The authors declare no conflicts of interest regarding the publication of this paper.

\section{References}

[1] Krabi, E., Assamoi, A., Ehon, F., Diawara, B., Niamké, S. and Thonart, P. (2015) [Production of Attiéké (Fermented Couscous of Cassava) in Abidjan]. European Scientific Journal, 11, 1857-7431. 
[2] Tanoh, B. (2016) Garba Ivoire. Journal d Afrique I'hebdo-Edition du 22-12-2016.

[3] Manda, P., Djédjé, S., Ehile, S., Koffi, M., Amani, N.G. and Aké, Y. (2012) Evaluation of Polycyclic Aromatic Hydrocarbons (PAHs) Content in Foods Sold in Abobo Market, Abidjan, Côte d'Ivoire. Journal of Toxicology and Environmental Health Sciences, 4, 99-105.

[4] Aladedunye, F.A. and Przybylski, K. (2009) Degradation and Nutritional Quality Changes of Oil during Frying. Journal of the American Oil Chemists Society, 86, 149-156. https://doi.org/10.1007/s11746-008-1328-5

[5] Dansou, P.I., Ahounou, F.J.I., Ahissou, H. and Tossou, R. (2008) The Nature Indices of the Fried Sauce "JA" and the Health of the Consumer. Revue du C.A.M.E.S.-Series A, 6, 10-11.

[6] Ziaiifar, A.M., Achir, N., Courtois, F., Trezzani, I. and Trystram, G. (2008) Review of Mechanisms, Conditions, and Factors Involved in the Oil Uptake Phenomenon during the Deep Fat Frying Process. International Journal of Food Science \& Technology, 43, 1410-1423. https://doi.org/10.1111/j.1365-2621.2007.01664.x

[7] Hosseini, H., Ghorbani, M., Meshginfar, N. and Mahoonak, A. (2016) A Review on Frying: Procedure, Fat, Deterioration Progress and Health Hazards. Journal of the American Oil Chemists' Society, 93, 445-466.

https://doi.org/10.1007/s11746-016-2791-Z

[8] Gondé, P. and Morin, O. (2012) [Optimization of the Choice of Oil in Industrial Frying: The Example Mc Cain]. OCL-Oilseeds and Fats, Crops and Lipids, 19, 96-100.

[9] Karakaya, S. and Simsek, S. (2010) Changes in Total Polar Compounds, Peroxide Value, Total Phenols and Antioxidant Activity of Various Oils Used in Deep Fat Frying. Journal of the American Oil Chemists' Society, 70, 1361-1366. https://doi.org/10.1007/s11746-011-1788-x

[10] Diabaté, M., Dossou, J., Nimaga, D., Gbogouri, A.G. and Amani, N.G. (2018) [Diagnostic Study of the Practices Frying Tuna of "Garba" Food Consumed in Abidjan (Côte d'Ivoire)]. International Journal of Biological and Chemical Sciences, 12, 1333-1344. https://doi.org/10.4314/ijbcs.v12i3.21

[11] Morrison, J.A., Glueck, C.J. and Wang, P. (2008) Dietary Trans Fatty Acid Intake Is Associated with Increased Fetal Loss. Fertility and Sterilty, 90, 385-390. https://doi.org/10.1016/j.fertnstert.2007.06.037

[12] INS (Institut National de la Statistique de Côte d'Ivoire) (2015) Rapport d'activités de l'Institut national de la statistique des résultats du $4{ }^{\text {ème }}$ Recensement Général de la Population et de l'Habitat (RGPH) de 2014. http://www.ins.ci/

[13] A.O.A.C.-Association of Official Analytical Chemistry (2000) Official Methods of Analysis of AOAC (17th Edition). Washington: AOAC.

[14] Tan, Y.-A. and Kuntom, A. (1993) Gas Chromatographic Determination of Hydrocarbons in Crude Palm Kernel Oil. Journal of AOAC International (USA), 76, 371-376.

[15] Chen, Y.-H., Xia, E.-Q., Xu, X.-R., Ling, W.-H., Li, S., Wu, S., Deng, G.-F., Zou, Z.-F., Zhou, J. and Li, H.-B. (2012) Evaluation of Acrylamide in Food from China by a LC/MS/MS Method. International Journal of Environmental Research and Public Health, 9, 4150-4158. https://doi.org/10.3390/ijerph9114150

[16] Bocar, K.M., Baïdy, B. and Emmanuel, B. (2011) Changes in Peroxide Value in Different Oils Food Heating Points. Sciences Lib Editions Mersenne, 3, 111-114.

[17] Aladedunye, F. and Przybylski, R. (2013) Frying Stability of High Oleic Sunflower 
Oils as Affected by Composition of Tocopherol Isomers and Linoleic Acid Content. Food Chemistry, 141, 2373-2378. https://doi.org/10.1016/j.foodchem.2013.05.061

[18] Zhang, J.-J., Wu, D., Liu, D.-H., Fang, Z.-X., Chen, J.-C., Hu, Y.-Q. and Ye, X.-Q. (2012) Effect of Cooking Styles on the Lipid Oxidation and Fatty Acid Composition of Grass Carp (Ctenopharynyodon idellus) Fillet. Journal of Food Biochemistry, 37, 212-219. https://doi.org/10.1111/j.1745-4514.2011.00626.x

[19] Vanessa, P. (2015) Development of Antioxidants for Frying Oils and Contribution to the Study of the Mechanism of Formation of Cyclic Monomers from Omega-3 Fatty Acids. MSc Thesis, Laval University, Quebec, Canada.

[20] Sasikan, K. and Wipawan, K. (2012) Effect of Vegetable Oil Blend and Frying Condition on Polar Compound Formation during Deep-Fat Frying of French Fries. Journal of Applied Sciences Research, 8, 4777-4782.

[21] Al-Khusaibi, M., Gordon, M.H., Lovegrove, J.A. and Niranjan, K. (2012) Frying of Potato Chips in a Blend of Canola Oil and Palm Olein: Changes in Levels of Individual Fatty Acids and Tocols. International Journal of Food Science \& Technology, 47, 1701-1709. https://doi.org/10.1111/j.1365-2621.2012.03024.x

[22] Bordin, K., Kunitake, M.T., Aracava, K.K. and Favaro-Trindade, C. (2013) Changes in Food Caused by Deep Fat Frying-A Review. Archivos Latinoamericanos de $\mathrm{Nu}$ trición, 63, 5-13.

[23] Pawar, D.P., Boomathi, S., Hathwar, S.C., Rai, A.K. and Modi, V.K. (2013) Effect of Conventional and Pressure Frying on Lipids and Fatty Acid Composition of Fried Chicken and Oil. Journal of Food Science and Technology, 50, 381-386. https://doi.org/10.1007/s13197-011-0331-2

[24] Aladedunye, F.A. (2015) Curbing Thermo-Oxidative Degradation of Frying Oils: Current Knowledge and Challenges. European Journal of Lipid Science and Technology, 117, 1867-1881. https://doi.org/10.1002/ejlt.201500047

[25] Stier, R.F. (2013) Ensuring the Health and Safety of Fried Foods. European Journal of Lipid Science and Technology, 115, 956-964.

https://doi.org/10.1002/ejlt.201300180

[26] Urbančič, S., Kolar, M.H., Dimitrijević, D., Demšar, L. and Vidrih, R. (2014) Stabilisation of Sunflower Oil and Reduction of Acrylamide Formation of Potato with Rosemary Extract during Deep-Fat Frying. LWT-Food Science and Technology, 57, 671-678. https://doi.org/10.1016/j.lwt.2013.11.002

[27] Nishida, C. and Uauy, R. (2009) WHO Scientific Update on Trans Fatty Acids: Introduction. European Journal of Clinical Nutrition, 63, S1-S4. https://doi.org/10.1038/ejen.2009.13

[28] Hunter, J.E., Zhang, J. and Kris-Etherton, P.M. (2010) Cardiovascular Disease Risk of Dietary Stearic Acid Compared with Trans, Other Saturated, and Unsaturated Fatty Acids: A Systematic Review. The American Journal of Clinical Nutrition, 91, 46-63. https://doi.org/10.3945/ajcn.2009.27661

[29] Pedreschi, F., Mariotti, M.S. and Grnaby, K. (2014) Current Issues in Dietary Acrylamide: Formation, Migration and Risk Assessment. Journal of Science of Food and Agriculture, 94, 9-20. https://doi.org/10.1002/jsfa.6349

[30] Saavedra, G., Aït-Ameur, L., Tessier, F., Pouillart, P., Sebekova, K., Lecerf, J.M. and Birlouez-Aragon, I. (2008) Les produits de Maillard issus de la cuisson ont-ils des effets biologiques? Sciences des Aliment, 28, 223-230. https://doi.org/10.3166/sda.28.223-230

[31] Tessier, F.J., Jacolot, P. and et Niquet-Léridon, C. (2012) La réaction de Maillard: cent ans de découvertes scientifiques. FFAS. 
[32] EFSA (2011) Scientific Report of EFSA-Results on Acrylamide Level in Food from Monitoring Years 2007-2009 and Exposure Assessment. EFSA Journal, 9, 2133.

[33] Krishna-Kumar, T. and Visvanathan, R. (2014) Acrylamide in Food Product: A Review. Journal of Food Processing \& Technology, 5, 344. https://doi.org/10.4172/2157-7110.1000344

[34] IARC (2010) Air Pollution, Part 1, Some Non-Heterocyclic Polycyclic Aromatic Hydrocarbons and Some Related Industrial Exposures. IARC Working Group on the Evaluation of Carcinogenic Risks to Humans, 92, 1-853.

[35] EFSA: European Food Safety Authority (2008) Les hydrocarbures aromatiques polycycliques dans l'alimentation-Avis du groupe scientifique sur les contaminants de la chaine alimentaire. The EFSA Journal, 724, 1-114. 